MAGNETNA REZONANCA SRCA U RANOJ DIJAGNOSTICI

INFLAMACIJE MIOKARDA NAKON KOVID-19 INFEKCIJE:

SERIJA SLUČAJEVA I PREGLED LITERATURE

PO IZBORU UREDNIKA

EDITOR'S CHOICE

\title{
CARDIAC MAGNETIC RESONANCE IMAGING IN EARLY DIAGNOSTICS OF MYOCARDIAL INFLAMMATION AFTER COVID-19: CASE SERIES AND LITERATURE REVIEW
}

\author{
Marija Zdravković1,2, Slobodan Klašnja', Maja Popović', Predrag Đuran ${ }^{1}$, Andrea Manojlović',

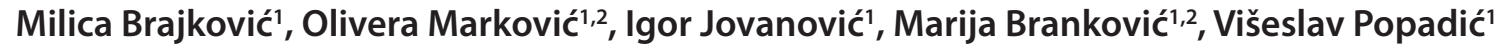 \\ 1 Kliničko-bolnički centar „Bežanijska kosa”, Beograd, Srbija \\ 2 Medicinski fakultet, Univerzitet u Beogradu, Beograd, Srbija \\ University Hospital Medical Center "Bežanijska kosa", Belgrade, \\ Serbia \\ 2 Faculty of Medicine, University of Belgrade, Belgrade, Serbia
}

\section{SAŽETAK}

lako je na početku svog pojavljivanja smatrana respiratornom bolešću, sa tipičnom prezentacijom po tipu bilateralne pneumonije, KOVID-19 je zapravo multisistemsko oboljenje sa mnogobrojnim ekstrapulmonalnim manifestacijama. U osnovi generalizovanog multisistemskog oštećenja nalazi se oštećenje endotelnih ćelija kardiovaskularnog sistema, izazvano udruženim delovanjem direktnog uticaja virusa i efektom cirkulišućih citokina na miokard i perikard, koje se može javiti u toku akutne faze infekcije ili nakon toga. Najčešći kardiovaskularni simptomi kod pacijenata, nakon akutne faze KOVID-19 infekcije, jesu zamaranje, malaksalost, kratak dah, bolovi u grudima, lupanje i preskakanje srca. Standardnim dijagnostičkim metodama se kod ovih pacijenata ne registruju značajne promene, mada inflamacija miokarda i pored toga može biti prisutna. Oštećenje miokarda takođe može biti supstrat za pogoršanje srčane insuficijencije, kao iza različite aritmije, potencijalno opasne po život, što je od izuzetnog značaja za dalje lečenje i prognozu. Magnetna rezonanca srca je sofisticirana, nejonizujuća dijagnostička metoda, koja može pružiti važne informacije u vezi sa funkcijom i volumenom leve i desne komore, tkivnom karakterizacijom i kvantifikacijom fibroznih promena u miokardu. Predstavlja zlatni standard u neinvazivnoj dijagnostici miokarditisa. Kod pacijenata sa prethodnom KOVID-19 infekcijom i postojećim kardiovaskularnim simptomima, mogu se registrovati tipični znaci miokarditisa na magnetnoj rezonanci srca, uključujući postojanje edema miokarda, nekroze i miokardne fibroze, odnosno ožiljka. Takođe, određenim novim, sofisticiranim sekvencama, u sklopu kardiomagnetne rezonance, moguće je registrovati diskretne promene koje mogu ukazivati na inflamaciju miokarda, bez jasno vidljivih promena na standardnim sekvencama.

U radu predstavljamo seriju slučajeva sa različitim obrascima inflamacije miokarda i perikarda nakon KOVID-19 infekcije, uz komparativni pregled trenutno najrelevantnijih naučnih podataka o mehanizmu, komplikacijama, lečenju i prognozi pacijenata sa post-KOVID miokarditisom, odnosno perikarditisom.

Ključne reči: KOVID-19, magnetna rezonanca, srce, miokarditis

\begin{abstract}
Although, in the beginning, it was considered a respiratory infection with bilateral pneumonia as its main manifestation, COVID-19 is more of a multisystemic disease with various extrapulmonary manifestations. Cardiovascular manifestations are caused by direct viral involvement or by the effects of different cytokines on the myocardium and can occur during the acute phase of the disease or in the post-acute stadium. The most common cardiovascular symptoms in the post-acute COVID-19 stadium are fatigue, shortness of breath, chest pain, and palpitations. Routine cardiovascular diagnostics in these patients is usually without significant findings, although underlying myocardial inflammation may be present. Myocardial damage can also be the substrate for the worsening of heart failure and different potentially life-threatening arrhythmias, which is extremely important for further treatment and prognosis. Cardiac magnetic resonance imaging is a sophisticated, non-radiating imaging modality that can provide important information regarding left and right ventricle volumes and function, tissue characterization, and scar quantification. It is the golden standard in non-invasive diagnostics of myocarditis. In patients with prior COVID-19 infection and cardiovascular symptoms, typical signs of myocarditis, including myocardial edema, necrosis, and myocardial scarring, may be seen in cardiac magnetic resonance. Also, there are sophisticated cardiac magnetic resonance imaging modalities that can register subtle changes in the myocardium, in terms of myocardial inflammation, without visible signs in standard sequences.
\end{abstract}

We present a case series of patients with different myocardial inflammation patterns, followed by a comprehensive review of potential pathophysiological mechanisms, complications, treatment and prognosis of patients with myocarditis or pericarditis after COVID-19.

Keywords: COVID-19, magnetic resonance imaging, heart, myocarditis 


\section{UVOD}

KOVID-19 je primarno respiratorna bolest uzrokovana SARS-KoV-2 virusom, ali sa mnogobrojnim ekstrapulmonalnim manifestacijama koje mogu značajno da utiču na dalje lečenje i prognozu, čineći ovu bolest multisistemskim oboljenjem sa neizvesnim ishodom lečenja i potencijalno mnogobrojnim post-KOVID komplikacijama [1]. Teška klinička slika kod pacijenata sa KOVID-19 infekcijom je rezultat povećane potrebe za kiseonikom od strane srca, oštećenja endotela, mikro i makrovaskularnih tromboza, kao i citokinske oluje. Pacijenti sa teškom formom bolesti podložniji su oštećenju miokarda, koje može biti izazvano direktnim citopatogenim efektom virusa ili indirektno, efektom cirkulišućih citokina na miokard [2]. U određenim slučajevima, kao rezultat različitih patofizioloških mehanizama, uključujući akutni infarkt miokarda, plućnu tromboemboliju, septički šok, miokarditis, perikarditis i druga stanja, miokardna povreda može biti uzrok pogoršanja srčane funkcije, razvoja slabosti srca i pojave malignih aritmija, što može voditi ka daljoj progresiji bolesti i mogućem smrtnom ishodu [3]. Znaci oštećenja miokarda, odnosno povrede miokarda, zabeleženi su kod 7,0\% do $17,0 \%$ hospitalizovanih pacijenata sa KOVID-19 infekcijom, dok je taj broj kod pacijenata $u$ intenzivnim negama viši, i kreće se od 22,0\% do $31,0 \%$ [4]. Pored oštećenja miokarda, koje se može javiti u toku same akutne faze KOVID-19 infekcije, određenim mehanizmima može doći do nastanka oštećenja i u daljem toku, nakon akutne faze bolesti, što dovodi do pojave različitih simptoma od strane kardiovaskularnog sistema, koji značajno mogu uticati na kvalitet života i prognozu ovih pacijenata [5]. Najčešći uzrok predstavlja inflamacija miokarda ili perikarda, koja se obično ne može registrovati na rutinskom ehokardiografskom pregledu, te zahteva dalju dijagnostiku i praćenje.

Magnetna rezonanca srca je sofisticirana, nejonizujuća dijagnostička metoda koja predstavlja zlatni standard u dijagnostici miokardne inflamacije, odnosno miokarditisa. Odlikuje se visokom reproducibilnošću i malim stepenom varijabilnosti $u$ interpretaciji nalaza, u odnosu na druge modalitete, a može pružiti značajne informacije $u$ vezi sa volumenom i funkcijom leve i desne komore, karakterizacijom tkiva i kvantifikacijom fibroznih promena, odnosno ožiljka u miokardu [6].

U Kliničko-bolničkom centru "Bežanijska kosa“, sa obukom kadra za kardiomagnetnu rezonancu započelo se 2014. godine, pod okriljem Evropskog udruženja kardiologa, dok je ova metoda u standardnu kliničku praksu uvedena od 2016. godine, od strane doc. dr Marije Zdravković. U međuvremenu je daljom edukacijom formiran tim za kardiomagnetnu rezonancu, sačinjen od kardiologa i radiologa, čime je postignut multidisciplinarni pristup u rešavanju dijagnostičkih dilema na

\section{INTRODUCTION}

COVID-19 is primarily a respiratory infection caused by the SARS-CoV-2 virus, but with multiple extrapulmonary manifestations that can significantly affect further patient treatment and prognosis, which makes it a multisystemic disease with an unpredictable course and potentially numerous post-COVID complications [1]. A severe clinical condition in patients with COVID-19 is the result of an increased demand on the heart in terms of oxygen, endothelial injury, micro and macrovascular thrombosis, and cytokine storm. Patients with a severe form of the disease are more susceptible to myocardial injury, which is caused by direct viral involvement or by the effects of different cytokines on the myocardium [2]. Sometimes, as the result of different pathophysiological mechanisms, including acute myocardial infarction, pulmonary embolism, septic shock, myocarditis, pericarditis and other conditions, myocardial injury can be the substrate for the worsening of heart function, the development of heart failure or malignant arrhythmias, which may lead to further clinical deterioration and potentially, death [3]. Myocardial injury has been detected in $7.0 \%$ to $17.0 \%$ of patients hospitalized with COVID-19, while the number of patients admitted to intensive care units with myocardial injury is higher, ranging from $22.0 \%$ to $31.0 \%$ [4]. Apart from myocardial injury in the milieu of acute COVID-19 infection, different substrates can cause myocardial damage in the post-COVID period, provoking different cardiovascular symptoms and affecting the patient's quality of life and prognosis [5]. The most common cause is myocardial inflammation, usually undetectable by routine echocardiography.

Cardiac magnetic resonance imaging (CMR) is a sophisticated non-radiating imaging modality that represents the golden standard in estimating myocardial inflammation or myocarditis. It has a high reproducibility and less inter-observer variability than other imaging modalities and can also provide important information regarding left and right ventricle volumes and function, tissue characterization, and scar quantification [6].

At the University Hospital Medical Center Bežanijska kosa, the training for cardiac magnetic resonance imaging started in 2014, under the auspices of the European Society of Cardiology, while the procedure was introduced as a standard diagnostic technique in 2016, by Assistant Professor Marija Zdravković. In the meantime, the CMR team was formed, comprised of both radiologists and cardiologists, whereby a multidisciplinary approach was achieved in resolving diagnostic dilemmas. In 2019, the University Hospital Medical Center Bežanijs$k a$ kosa received advanced technical hardware and software improvements to the Avanto 1.5 T CMR machine (Siemens), accomplishing sophisticated methods of 
kardiomagnetnoj rezonanci. Od 2019. godine, u Kliničko-bolničkom centru „Bežanijska kosa“, posebnim tehničkim usavršavanjima hardvera i softvera na aparatu Avanto 1,5 T (Siemens) postignute su sofisticirane metode tkivne karakterizacije sa T1 i T2 mapama (pre i postkontrastne sekvence), što je značajno doprinelo većoj senzitivnosti i specifičnosti samog pregleda. Od maja 2021. godine, u Laboratoriji za kardiomagnentnu rezonancu KBC „Bežanijska kosa”, u standardnu dijagnostičku proceduru je uveden i adenozinski stres test na kardiomagnetnoj rezonanci, čime je postignut najviši nivo dijagnostičkih standarda svetski poznatih laboratorija za kardiomagnetnu rezonancu.

Kroz prijemno-trijažnu ambulantu KBC "Bežanijska kosa" je, od 22. juna 2020. godine do datuma predaje rada (07. 11. 2021.), pregledano i trijažirano za dalje lečenje 41.126 pacijenata. Kardiomagnetna rezonanca je urađena kod 316 pacijenata sa sumnjom na post-KOVID mioperikardni sindrom. Kod 292 pacijenta $(92,4 \%)$ dobijen je patološki nalaz koji odgovara mioperikardnom post-KOVID sindromu. $U$ radu predstavljamo seriju slučajeva sa različitim obrascima inflamacije miokarda i perikarda nakon KOVID-19 infekcije, dijagnostikovanih na magnetnoj rezonanci srca, u Laboratoriji za magnetnu rezonancu srca i krvnih sudova u KBC "Bežanijska kosa", uz komparativni pregled trenutno najrelevantnijih naučnih podataka o mehanizmu, komplikacijama, lečenju i prognozi pacijenata sa post-KOVID miokarditisom, odnosno perikarditisom.

\section{SERIJA SLUČAJEVA}

\section{Prikaz slučaja 1}

Dvadesetčetvorogodišnja pacijentkinja, dva meseca nakon asimptomatske KOVID-19 infekcije, prijavila je tegobe $u$ vidu zamaranja, lupanja srca i vrtoglavica. Simptomi su bili izraženiji u toku fizičke aktivnosti. Ehokardiografskim pregledom registrovana je očuvana globalna sistolna funkcija, očuvana dijastolna funkcija leve komore, bez ispada u segmentnoj kontraktilnosti, bez promena u perikardu. Elektrokardiografskim zapisom registrovan je sinusni ritam, frekvencije $95 / \mathrm{min}$, sa jednom ventrikularnom ekstrasistolom, bez značajnih promena u ST segmentu iT talasu. Dvadesetčetvoročasovnim praćenjem Holter EKG-om registrovano je ukupno 4.339 epizoda ventrikularnih ekstrasistola, polimorfnih, iz 5 fokusa, sa 514 epizoda bigeminije, 20 epizoda trigeminije, 30 kupleta i 2 epizode non-sustained ventrikularne tahikardije. Visoko-senzitivni troponin T i C-reaktivni protein bili su povišeni: $36 \mathrm{pg} / \mathrm{ml}$ (referentna vrednost: $0-14 \mathrm{pg} / \mathrm{ml}$ ) i 30,9 mg/L (referentna vrednost: $<5 \mathrm{mg} / \mathrm{L})$, pojedinačno.

Uzimajući u obzir postojeće tegobe, ehokardiografski nalaz, nalaz dvadesetčetvoročasovnog praćenja tissue characterization with T1 i T2 mapping (pre- and post-contrast sequences), thereby significantly improving the sensitivity and specificity of this imaging modality. As of May 2021, at the Laboratory for Cardiac Magnetic Resonance Imaging of the University Hospital Medical Center Bežanijska kosa, the adenosine stress CMR test has been in use, as a part of standard clinical procedure, and this methodological achievement has provided the highest scientific standard for the CMR Lab. Since the beginning of the COVID-19 pandemic until now, more than 316 cardiac magnetic resonance examinations have been performed in patients with suspected myocardial-pericardial post-COVID-19 syndrome.

At the COVID-19 triage facility of the University Hospital Medical Center Bežanijska kosa, in the period starting from June 22, 2020, to the date when this manuscript was finished (November 7, 2021), a total of 41,126 patients were examined, diagnosed and placed into the system for COVID-19 treatment. Cardiac magnetic resonance imaging was performed in 316 patients suspected of the syndrome of post-COVID myopericarditis. In 292 patients (92.4\%), pathological findings indicating the syndrome of post-COVID myopericarditis were detected. In this paper, we present a case series of patients with different myocardial inflammation patterns, detected by cardiac magnetic resonance imaging, and we also present a comprehensive comparative review of currently most relevant research data related to the pathophysiological mechanism, complications, treatment and prognosis of patients with myocardial or pericardial inflammation after COVID-19.

\section{CASE SERIES}

\section{Case report 1}

A 24-year-old female patient, two months after asymptomatic COVID-19 infection, was feeling fatigue, palpitations and dizziness. The symptoms were pronounced during physical activity. Echocardiography revealed a preserved ejection fraction, without wall motion abnormalities, without signs of pericardial effusion. ECG revealed a normal sinus rhythm, of a $95 / \mathrm{min}$ frequency, with a single ventricular extrasystole, without ST and T abnormalities. 24-hour Holter monitoring showed 4,339 episodes of ventricular extrasystolic beats, polymorphic, from five focuses, with 514 episodes of bigeminy, 20 episodes of trigeminy, 30 couplets, and 2 episodes of non-sustained ventricular tachycardia. High-sensitive troponin $\mathrm{T}$ and C-reactive protein were $36 \mathrm{pg} / \mathrm{ml}$ (ref. range: 0 - $14 \mathrm{pg}$ / $\mathrm{ml}$ ) and $30.9 \mathrm{mg} / \mathrm{L}$ (ref range: $<5 \mathrm{mg} / \mathrm{L}$ ), respectively.

Bearing in mind the finding of 24-hour Holter monitoring and the laboratory parameters, the patient was referred for cardiac magnetic resonance imaging. Cardiac magnetic resonance imaging was performed using the standardized cardiac imaging protocol. Myocardial 
Holter EKG-om, kao i nalaz laboratorijskih analiza, pacijent je radi dalje dijagnostike upućen na magnetnu rezonancu srca. Magnetna rezonanca srca učinjena je po standardizovanom protokolu za kardiomagnetnu rezonancu, na aparatu Siemens Avanto, 1,5 T. Na STIR sekvencama registrovan je edem miokarda, dok su na T2 i nativnim T1 miokardnim mapama registrovane povišene prosečne vrednosti $T 2$ vremena i nativnog $T 1$ vremena $u$ apikalnom septalnom segmentu, u medioapikalnim anterolateralnim segmentima, kao i u mediobazalnim inferiornim i inferolateralnim segmentima (Slika 1). Prosečna vrednost T2 vremena na miokardnim mapama je bila $68 \mathrm{~ms}$, dok je prosečna vrednost nativnog T1 vremena bila $1.261 \mathrm{~ms}$. Vrednost frakcije ekstracelularnog volumena bila je 28,1\% (referentna vrednost: $25,3 \pm 3,5 \%$ na 1,5 T). Nakon davanja paramagnetnog kontrastnog sredstva na bazi gadolinijuma, uočeno je postojanje laminarnog $L G E$ fenomena, mezomiokardno $\mathrm{u}$ anterolateralnim segmentima, kao i subepikardno, u medijalnom inferiornom segmentu. Takođe je registrovan i fenomen kasnog prebojavanja perikarda na LGE sekvencama (engl. late pericardal enhancement), ispred lateralnog zida, sa efuzijom u perikardu do $7 \mathrm{~mm}$, što ukazuje na inflamaciju perikarda sa posledičnim perikardnim izlivom (Slika 2). U trenutku prvog pregleda, globalna sistolna funkcija bila je očuvana. Kontrolnim ehokardiografskim pregledom, nakon mesec dana, registrovan je pad u ejekcionoj frakciji na $40,0 \%$ sa perikardnim priraslicama uz lateralni zid. Ordinirana je terapija prema smernicama Evropskog udruženja kardiologa, na koju je došlo do redukcije simptoma i poboljšanja opšteg stanja, uz indikovano dalje praćenje od strane kardiologa.

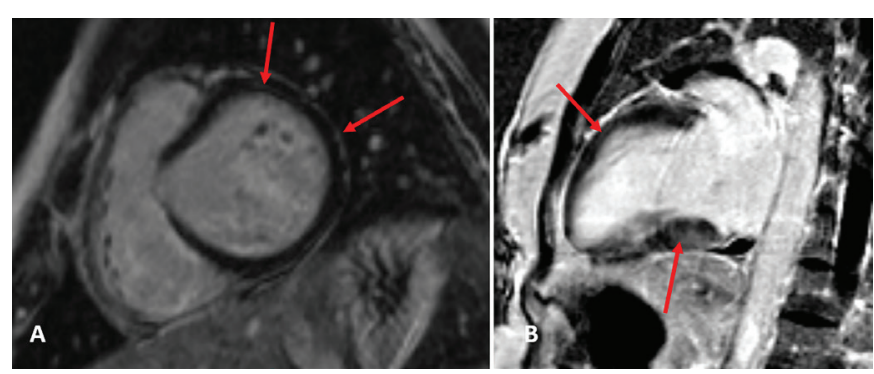

Slika 2. A) Postkontrastna sekvenca (LGEMAG studija, presek po kratkoj osi): Mezomiokardni LGE fenomen u bazalnom anterolateralnom segmentu uz fenomen kasnog prebojavanja perikarda na $L G E$ sekvencama (engl. late pericardial enhancement) uz lateralni zid leve komore; B) Postkontrastna sekvenca (LGE PSIR studija, presek dve šupljine): Mezomiokardni LGE fenomen u medijalnom anteriornom segmentu i subepikardni LGE fenomen u medijalnom inferiornom segmentu

Figure 2. A) Post-contrast sequence (LGE MAG study, short axis view): Mesomycardial LGEphenomenon in the basal anterolateral segment with late pericardial enhancement phenomenon in front of the lateral wall of the left ventricle; B) Post-contrast sequence (LGE PSIR study, two- chamber view): Mesomycardial LGE phenomenon in the medial anterior segment and subepicardial LGE phenomenon in the medial inferior segment

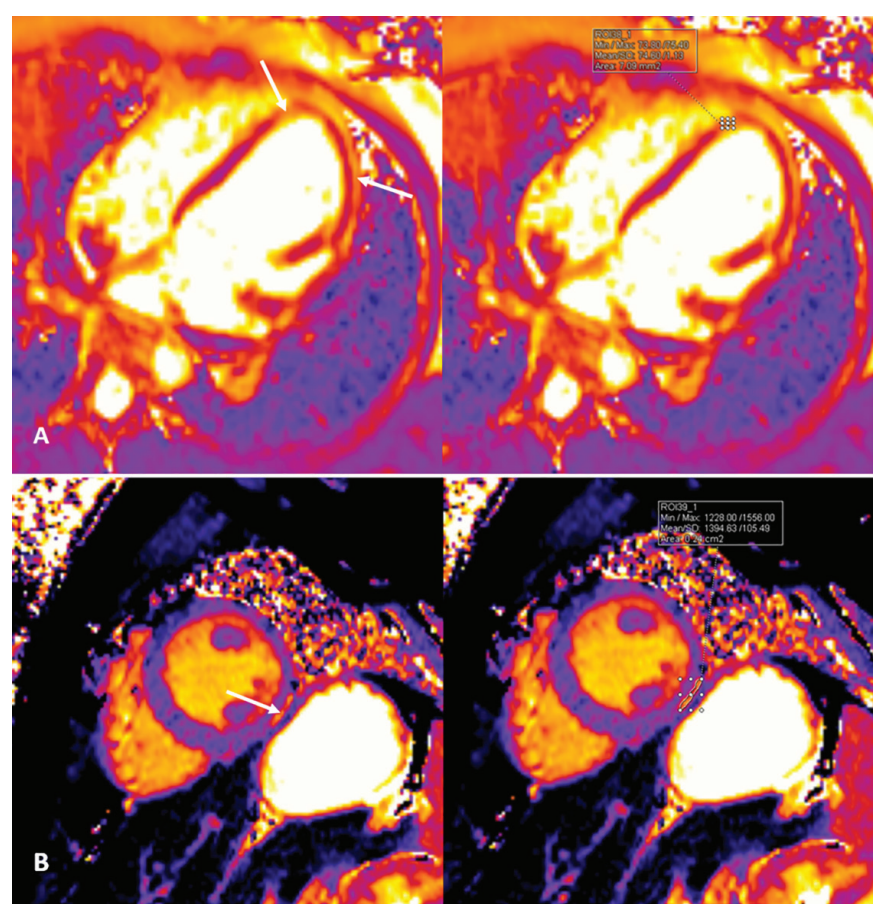

Slika 1. A) T2 mape, presek 4 šupljine: Povišene vrednosti T2 vremena u apikalnom septalnom segmentu, kao i u medioapikalnom lateralnom segmentu; B) Nativne T1 mape, presek po kratkoj osi: povišene vrednosti nativnog T1 vremena u medijalnom inferolateralnom segmentu

Figure 1. A) T2 myocardial mapping, four-chamber view: Prolonged values of mean T2 time in the apical septal segment and the medioapical lateral segment; B) Native T1 myocardial mapping, short axis view: Prolonged mean native T1 time in the medial inferolateral segment

edema was registered on STIR sequences, while prolonged mean $\mathrm{T} 2$ time and native $\mathrm{T} 1$ time was registered in the apical septal segment, in the medial apical anterolateral segments, as well as in the mid-base inferior and inferolateral segments (Figure 1). The mean T2 time on the myocardial mapping sequences was $68 \mathrm{~ms}$, while the mean native $T 1$ time was $1,061 \mathrm{~ms}$. The extracellular volume fraction (ECV) was 28.1 (reference range: $25.3 \pm$ $3.5 \%$ at $1.5 \mathrm{~T}$ ). After the application of the gadolinium contrast medium, the LGE phenomenon was observed in the anterior lateral segments mesomyocardially and subepicardially, in the medial inferior segment. Late pericardial enhancement in front of the lateral wall with effusion up to $7 \mathrm{~mm}$ was also noted, indicating pericardial inflammation with consequent pericardial effusion (Figure 2). The global ejection fraction was preserved at the moment of the first examination. Follow-up echocardiography, after one month, revealed a decreased ejection fraction of $40.0 \%$ and pericardial accretion in front of the lateral wall. Optimal medical therapy was introduced according to the guidelines of the European Society of Cardiology, which led to the withdrawal of symptoms and an improvement in the patient's overall condition. It was indicated that the patient needed further cardiological follow-up. 


\section{Prikaz slučaja 2}

Dvadesetosmogodišnja pacijentkinja hospitalizovana je zbog KOVID-19 infekcije, sa pretežno gastrointestinalnim simptomima po tipu dijarealnog sindroma, kao i sa mijalgijom i kašljem, uz održavanje febrilnosti i subfebrilnosti tokom 10 dana od početka oboljenja. Tokom hospitalizacije, po protokolu je 8 . dana urađena kompjuterizovana tomografija (CT) grudnog koša, na kojoj nisu bili prisutni znakovi pneumonije. Na kontrolnim radiografijama nije bilo znakova progresije nalaza. Šest meseci nakon infekcije javile su se tegobe u vidu palpitacija, osećaja nestabilnosti, nelagodnosti u grudima, izraženog zamora i ubrzanog rada srca (puls uglavnom preko 120/min), čak i pri fizičkoj aktivnosti manjeg intenziteta. Ehokardiografskim pregledom je registrovana očuvana ejekciona frakcija, bez segmentnih ispada u kontraktilnosti i bez znakova perikardnog izliva. Elektrokardiografskim zapisom registrovan je normalan sinusni ritam, frekvencije $77 / \mathrm{min}$, bez značajnih promena u ST segmentu i T talasu. Dvadesetčetvoročasovnim praćenjem Holter EKG-om registrovana je jedna pojedinačna supraventrikularna ekstrasistola.

Imajući u vidu da su kardiovaskularni simptomi postali izraženiji, kako u mirovanju, tako i tokom fizičke aktivnosti, paciientkinia ie, radi dalie dijaqnostike,
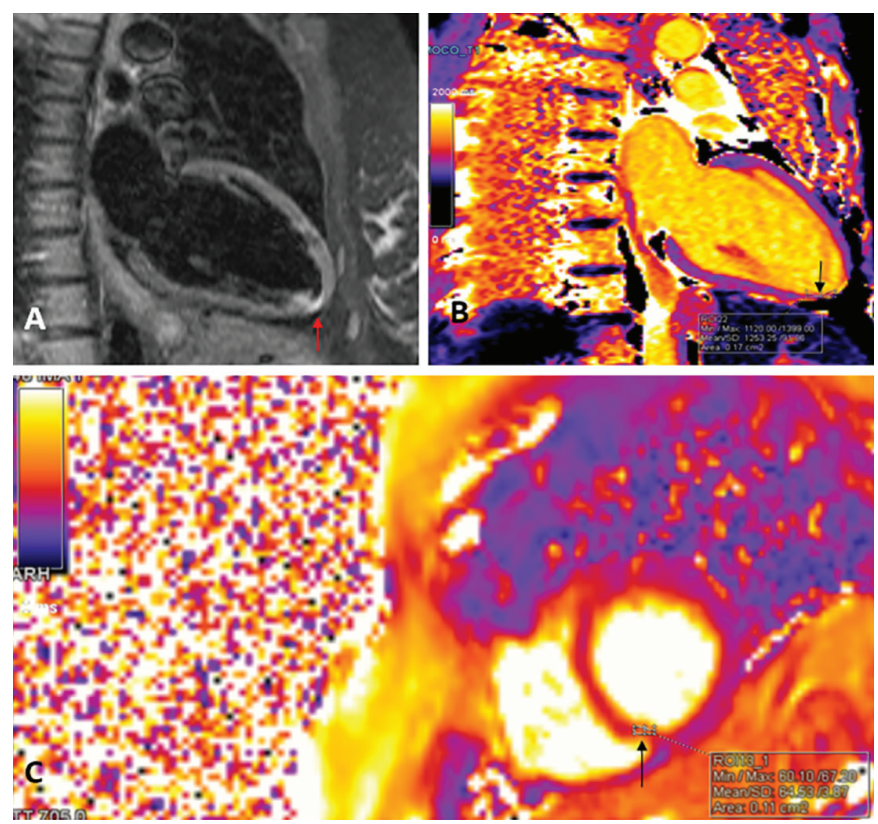

Slika 3. A) Prekontrastna STIR T2W sekvenca, presek dve šupljine: Transmuralni edem miokarda u apikalnom inferiornom segmentu; B) Nativna T1 mapa, presek dve šupljine: Povišene vrednosti nativnog T1 vremena u apikalnom inferiornom segmentu (edem miokarda); C) T2 mapa, presek po kratkoj osi: Povišene vrednosti 2 vremena u medijalnom inferoseptalnom segmentu (edem miokarda)

Figure 3. A) Pre-contrast STIR T2W sequence, two-chamber view: Transmural edema of the myocardium in the apical inferior segment; B) Native T1 myocardial mapping, two-chamber view: Prolonged mean native T1 time in the apical inferior segment (myocardial edema); C) T2 myocardial mapping, short axis view: Prolonged mean T2 time in the medial inferoseptal segment (myocardial edema)

\section{Case report 2.}

A 28-year-old woman was hospitalized due to COVID-19, with predominantly gastrointestinal symptoms (diarrhea), but also with myalgia and a cough. She had been febrile or with subfebrile body temperature throughout the first 10 days of the illness. According to protocol, during hospitalization (on the $8^{\text {th }}$ day), computed tomography imaging (CT) of the thorax was performed, without signs of pneumonia. Follow-up radiographies showed no signs of further progression. Six months after the infection the patient began feeling palpitations, instability, chest discomfort, excessive fatigue and her heart rate was usually above 120/min, even during light physical activity. Echocardiography revealed a preserved ejection fraction, without wall motion abnormalities and without signs of pericardial effusion. ECG revealed normal sinus rhythm, of a $77 /$ min frequency, without ST and T abnormalities. 24-hour Holter monitoring revealed a single supraventricular extrasystolic beat.

Bearing in mind the fact that the cardiovascular symptoms had become more pronounced, both at rest and during physical activity, the patient was referred for cardiac magnetic resonance imaging, for further diagnostics. Cardiac magnetic resonance imaging was performed using the standardized cardiac imaging protocol on the Siemens Avanto, 1.5 T machine. On STIR sequences, a small zone of transmural myocardial edema in the apical inferior segment was registered, as well as zones of prolonged $\mathrm{T} 2$ time and native $\mathrm{T} 1$ time on myocardial mapping sequences, in the apical inferior segment, the medial septal segment and the medial lateral segment (Figure 3). The mean T2 time on myocardial mapping sequences was $72 \mathrm{~ms}$, while the mean native $\mathrm{T} 1$ time was $1.348 \mathrm{~ms}$. Extracellular volume fraction $(E C V)$ was within the reference range. After the application of the gadolinium contrast medium, the transmural LGE phenomenon was observed in the medial

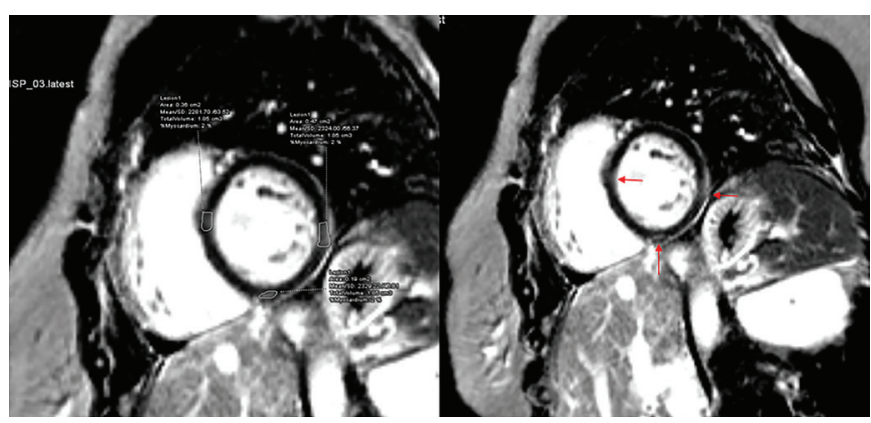

Slika 4. Postkontrastna sekvenca (LGE PSIR studija), presek po kratkoj osi: Transmuralni LGE fenomen u medijalnom inferoseptalnom i medijalnom inferolateralnom segmentu, subepikardni LGE fenomen u medijalnom inferiornom segmentu

Figure 4. Post-contrast sequence (LGE PSIR study), short axis view: Transmural LGE phenomenon in the medial inferoseptal segment and the medial inferolateral segment, subepicardial LGE phenomenon in the medial inferior segment 

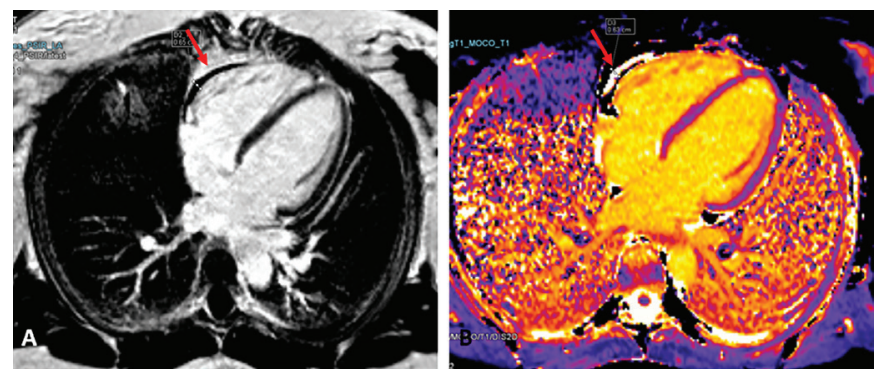

Slika 5. A) Postkontrastna sekvenca (LGE PSIR studija), presek četiri šupljine: Perikardni izliv uz slobodni zid desne komore; B) Nativna T1 mapa, presek četiri šupljine: Perikardni izliv uz slobodni zid desne komore

Figure 5. A) Post-contrast sequence (LGE PSIR study), four-chamber view: Pericardial effusion in front of the right ventricular free wall; B) Native T1 myocardial mapping, four-chamber view: Pericardial effusion in front of the right ventricular free wall

upućena na magnetnu rezonancu srca. Magnetna rezonanaca srca učinjena je po standardizovanom protokolu za kardiomagnetnu rezonancu, na aparatu Siemens Avanto, 1,5 T. Na STIR sekvencama registrovana je manja zona transmuralnog edema miokarda u apikalnom inferiornom segmentu, dok su na T2 i nativnim T1 miokardnim mapama registrovane povišene prosečne vrednosti $\mathrm{T} 2$ vremena i nativnog $\mathrm{T} 1$ vremena $\mathrm{u}$ miokardu, i to $\mathrm{u}$ apikalnom inferiornom segmentu, medijalnom inferoseptalnom segmentu i medijalnom inferolateralnom segmentu (Slika 3). Prosečna vrednost $\mathrm{T} 2$ vremena na miokardnim mapama je bila 72 $\mathrm{ms}$, dok je prosečna vrednost nativnog $\mathrm{T} 1$ vremena bila $1.348 \mathrm{~ms}$. Vrednost frakcije ekstracelularnog volumena bila je u referentnim vrednostima. Nakon primene paramagnetnog kontrastnog sredstva na bazi gadolinijuma, registrovan je transmuralni $L G E$ fenomen (engl. late gadolinuim enhancement) u medijalnom inferoseptalnom i inferolateralnom segmentu, kao i subepikardni LGE fenomen $u$ medijalnom inferiornom segmentu (Slika 4). Perikard je bio sa izlivom, maksimalne debljine $7 \mathrm{~mm}$, uz slobodan zid desne komore (Slika 5).

\section{Prikaz slučaja 3}

Šezdesetdvogodišnji muškarac, mesec dana nakon preležane KOVID-19 infekcije, osećao je palpitacije i nelagodnost u grudima, bez dispneje, bolova u grudima, gubitka svesti ili otoka nogu. Ehokardiografskim pregledom registrovana je uvećana leva komora, globalno hipokontraktilna, sa početno sniženom ejekcionom frakcijom (EF 45-50\%), kao i sitnozrnasto izmenjen interventrikularni septum i uvećana leva pretkomora. Elektrokardiografskim zapisom registrovan je normalni sinusni ritam, frekvencije $67 / \mathrm{min}$, kao i AV blok I stepena, bez značajnih promena u ST segmentu i T talasu. Dvadesetčetvoročasovnim praćenjem Holter EKG-om registrovane su 294 epizode ventrikularnih inferosepetal and inferolateral segments, as well as the subepicardial LGE phenomenon in the medial inferior segment (Figure 4). The pericardium was with effusion, and its maximum thickness was $7 \mathrm{~mm}$ (Figure 5).

\section{Case report 3.}

One month after COVID-19, a 62-year-old man was feeling palpitations and chest discomfort, without dyspnea, chest pain, loss of consciousness or swelling of the legs. Echocardiography revealed an enlarged left ventricle, globally hypocontractile, with an initially decreased ejection fraction (EF 45-50\%), an interventricular septum with fibrous fine-grained changes, and an enlarged left atrium. ECG revealed normal sinus rhythm (frequency of $67 / \mathrm{min}$ ), as well as AV block grade I, without ST and T abnormalities. 24-hour Holter monitoring showed 294 episodes of ventricular extrasystolic beats, single, from two focuses, with 3 couplets of monomorphic ventricular extrasystolic beats, two episodes of ventricular tachycardia (monomorphic ventricular extrasystolic beats with a salvo of 15 , in the first one) during night sleep, and two episodes of non-sustained ventricular tachycardia (a salvo of 11 ventricular extrasystolic beats, in the second one).

Bearing in mind the echocardiography finding and the 24-hour Holter monitoring results, as well as laboratory parameters, the patient was referred for cardiac magnetic resonance imaging. Cardiac magnetic resonance (CMR) imaging was performed using the standardized cardiac imaging protocol, on the Siemens Avanto, 1.5 T machine. CMR showed a dilated left ventricle, globally hypocontractile, more pronounced in the basal and medial lateral segments, where the walls were thinned. It also revealed reduced ejection fraction (EF 44.97\%), as well as increased left ventricular end-diastolic (EDVI $\left.145.9 \mathrm{ml} / \mathrm{m}^{2}\right)$ and end-systolic $\left(80.3 \mathrm{ml} / \mathrm{m}^{2}\right)$ volumes. Myocardial edema was not registered on STIR sequences. Myocardial mapping showed diffusely inhomogeneous signal intensity in the myocardium, more pronounced in the basal and medial anterior and inferior segments (Figure 6). The mean T2 time on myocardial mapping sequences was $57 \mathrm{~ms}$, while the mean native T1 time was $1,290 \mathrm{~ms}$. The extracellular volume fraction (ECV) was $26.8 \%$. Rest perfusion study showed a perfusion defect in the subendocardial zone of the lateral wall (Figure 7). After application of the gadolinium contrast medium, the mesomyocardial LGE phenomenon was observed in the basal anterior, anteroseptal, and inferoseptal segments, covering $2.0 \%$ of the left ventricular myocardial mass. This type of distribution of the LGE phenomenon indicates myocarditis. The subendocardial LGE phenomenon was also registered in all lateral and inferolateral segments, covering $8,0 \%$ of the 
ekstrasistola, pojedinačnih, iz dva fokusa, sa 3 kupleta monomorfnih ventrikularnih ekstrasistola, 2 epizode non-sustained ventrikularne tahikardije (sa 11 i 15 ventrikularnih ekstrasistola u nizu).

Imajući u vidu postojeću simptomatologiju, nalaz ehokardiografskog pregleda i dvadesetčetvoročasovnog praćenja Holter EKG-om, pacijent je upućen na magnetnu rezonancu srca, radi dalje dijagnostike. Magnetna rezonanaca srca učinjena je po standardizovanom protokolu za kardiomagnetnu rezonan$\mathrm{cu}$, na aparatu Siemens Avanto, 1,5 T. Pregledom srca magnetnom rezonancom, registrovana je dilatirana leva komora, globalno hipokontraktilna, izraženije u bazalnim i medijalnim lateralnim segmentima, koji su bili istanjenog zida. Takođe je registrovana i snižena ejekciona frakcija (EF 44,97\%), kao i povišeni end-dijastolni (EDVI 145,9 ml/ $\mathrm{m}^{2}$ ) i end-sistolni (ESVI $80,3 \mathrm{ml} /$ $\mathrm{m}^{2}$ ) volumen leve komore. Na STIR sekvencama nije registrovan edem miokarda. Na T2 i nativnim T1 miokardnim mapama registrovan je difuzno nehomogen intenzitet signala miokarda, izraženije u bazalnim i medijalnim anteriornim i inferoseptalnim segmentima (Slika 6). Prosečna vrednost T2 vremena na miokardnim mapama je iznosila $57 \mathrm{~ms}$, a prosečna vrednost nativnog T1 vremena je bila 1.290 ms. Vrednost frakcije ekstracelularnog volumena bila je $26,8 \%$. Studija perfuzije miokarda u miru pokazala je defekt u perfuziji subendokardnih slojeva svih lateralnih i inferolateralnih segmenata leve komore (Slika 7). Nakon primene paramagnetnog kontrastnog sredstva na bazi gadolinijuma, uočen je mezomiokardni LGE fenomen u bazalnom anteriornom, anteroseptalnom i inferoseptalnom segmentu, koji zahvata oko 2,0\% ukupne mase miokarda leve komore. Ovaj tip distribucije LGE fenomena je indikativan za miokarditis. Takođe je registrovan i subendokardni $L G E$ fenomen, u svim lateralnim i inferolateralnim segmentima, koji zahvata oko $8,0 \%$ ukupne mase miokarda leve komore i po svojoj distribuciji odgovara vaskularnoj etiologiji (Slika 8). U zonama u kojima se uočavao subendokardni $L G E$ fenomen na postkontrastnim T1 miokardnim mapama, uočene se snižene vrednosti postkontrastnog $\mathrm{T} 1$ vremena, što je govorilo u prilog ireverzibilne hronične ishemije i ukazivalo na postojanje fibroze miokarda (Slika 9). Viđene su i perikardne adhezije uz lateralni zid leve komore.

Uzimajući u obzir nalaz magnetne rezonance srca, koji je pored miokarditisa ukazivao i na koronarnu bolest srca, pacijent je upućen na koronarografiju. Koronarografijom je opisana trosudovna koronarna bolest sa okludiranom cirkumfleksnom arterijom i prvom optuznom marginalnom granom, granična stenoza na levoj prednjoj descendentnoj arteriji, kao i angiografski značajna stenoza na desnoj koronarnoj arteriji.

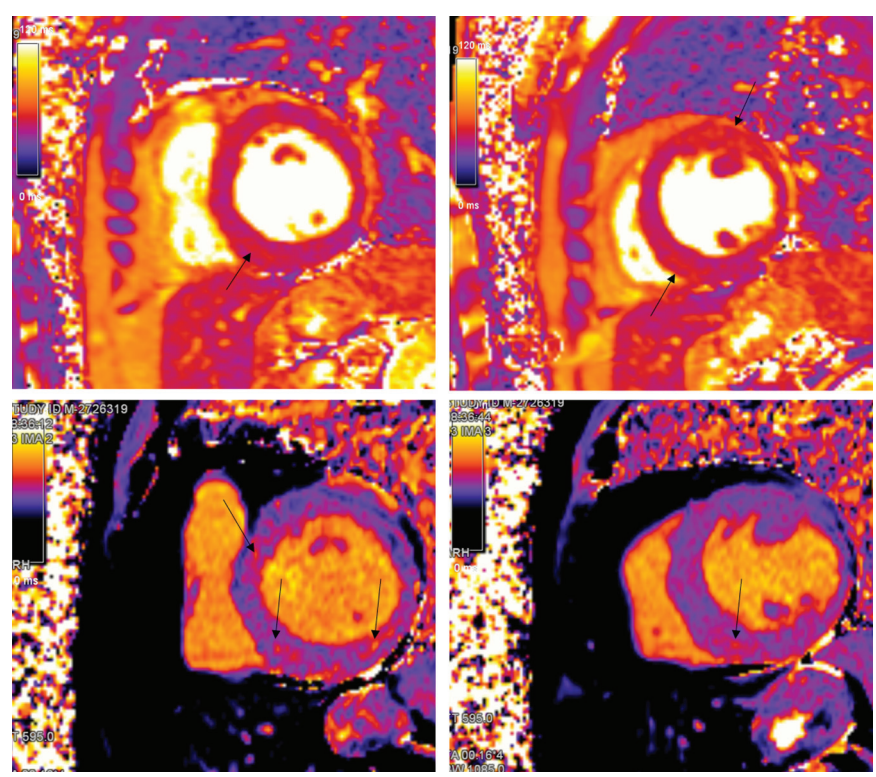

Slika 6. T2 i nativne T1 sekvence, presek po kratkoj osi: Nehomogene vrednosti T2 i nativnog T1 vremena u bazalnim i medijalnim anteriornim i inferoseptalnim segmentima (zone označene strelicama)

Figure 6. T2 and native T1 myocardial mapping sequences: Inhomogenous mean $\mathrm{T} 2$ and native $\mathrm{T} 1$ myocardial mapping values in the basal and medial anterior and inferoseptal segments (zones marked with arrows)

left ventricular myocardial mass, which, according to its distribution, corresponds with vascular etiology (Figure 8). In the segments with registered subendocardial LGE phenomenon, post-contrast $\mathrm{T} 1$ myocardial mapping revealed zones of low mean post-contrast $\mathrm{T} 1$ time, indicating irreversible chronic ischemia and myocardial fibrosis (Figure 9). The pericardium has adhesions along the lateral wall of the left ventricle.

In view of the CMR finding which, in addition to myocarditis, also indicated coronary artery disease, the patient was referred for coronary angiography. Coronary angiography showed three-vessel disease with an occluded circumflex artery, an occluded first obtuse marginal branch, and intermediate stenosis of the left anterior descending artery (LAD), as well as significant
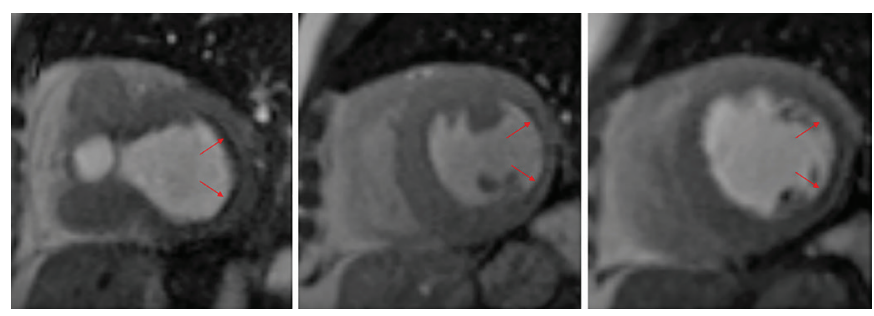

Slika 7. Postkontrastna sekvenca (perfuzija u miru), presek po kratkoj osi (bazalni, medijalni i apikalni presek): Subendokardni defekt u perfuziji u svim segmentima lateralnog zida

Figure 7. Post-contrast sequence (rest perfusion), short axis stack (basal, medial and apical view): Subendocardial defect in the perfusion of all lateral wall segments 

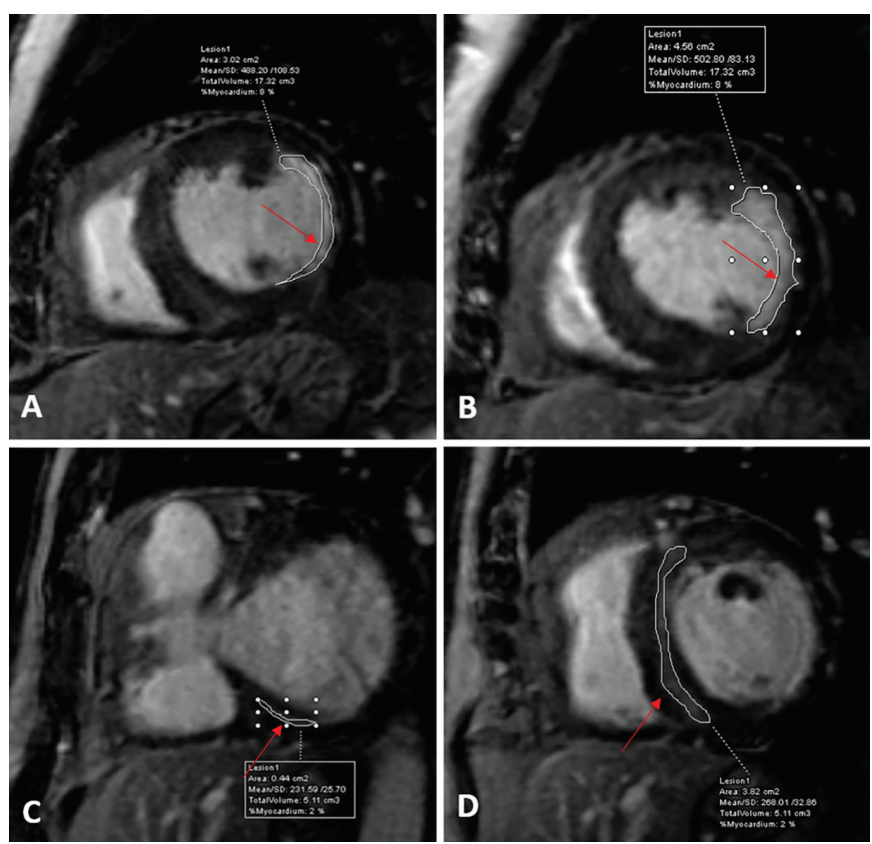

Slika 8. A) Postkontrastna sekvenca (LGEMAG studija), presek po kratkoj osi: Subendokardni $L G E$ fenomen u medijalnom anterolateralnom i inferolateralnom segmentu (vaskularna distribucija); B) Postkontrastna sekvenca (LGEMAG studija), presek po kratkoj osi: Subendokardni LGE fenomen u apikalnom lateralnom segmentu (vaskularna distribucija); C) Postkontrastna sekvenca (LGEMAG studija), presek po kratkoj osi: Mezomiokardni LGE fenomen u bazalnom inferoseptalnom segmentu (nevaskularna distribucija - miokarditis); D) Postkontrastna sekvenca (LGEMAG studija), presek po kratkoj osi: Mezomiokardni LGE fenomen u bazalnom anteriornom, anteroseptalnom i inferoseptalnom segmentu (nevaskularna distribucija - miokarditis)

Figure 8. A) Post-contrast sequence (LGE MAG study), short axis view: Subendocardial LGE phenomenon in the medial anterolateral and inferolateral segments (vascular distribution); B) Post-contrast sequence (LGE MAG study), short axis view: Subendocardial LGE phenomenon in the apical lateral segment (vascular distribution); C) Post-contrast sequence (LGE MAG study), short axis view: Mesomyocardial LGE phenomenon in the basal inferoseptal segment (non-vascular distribution - myocarditis); D) Post-contrast sequence (LGE MAG study), short axis view: Mesomyocardial LGE phenomenon in the basal anterior, anteroseptal and inferoseptal segments (non-vascular distribution - myocarditis)

Pacijent je prikazan kardiohirurškom konzilijumu, koji je indikovao invazivnu procenu hemodinamske značajnosti lezije na levoj prednjoj descendentnoj arteriji (engl. left anterior descending artery - $L A D$ ), te potom odluku o daljem lečenju. S obzirom da je nakon učinjene invazivne hemodinamske procene značajnosti pokazano da granična stenoza na $L A D$ nije od hemodinamskog značaja, učinjena je perkutana koronarna intervencija desne koronarne arterije, te nastavak optimalne medikamentne terapije uz maksimalnu korekciju aterosklerotskih faktora rizika. Ovaj slučaj pokazuje da kod istog pacijenta možemo imati dve etiološki različite promene na srčanom mišiću - i koronarnu bolest i fokalnu zapaljensku leziju po tipu miokarditisa.

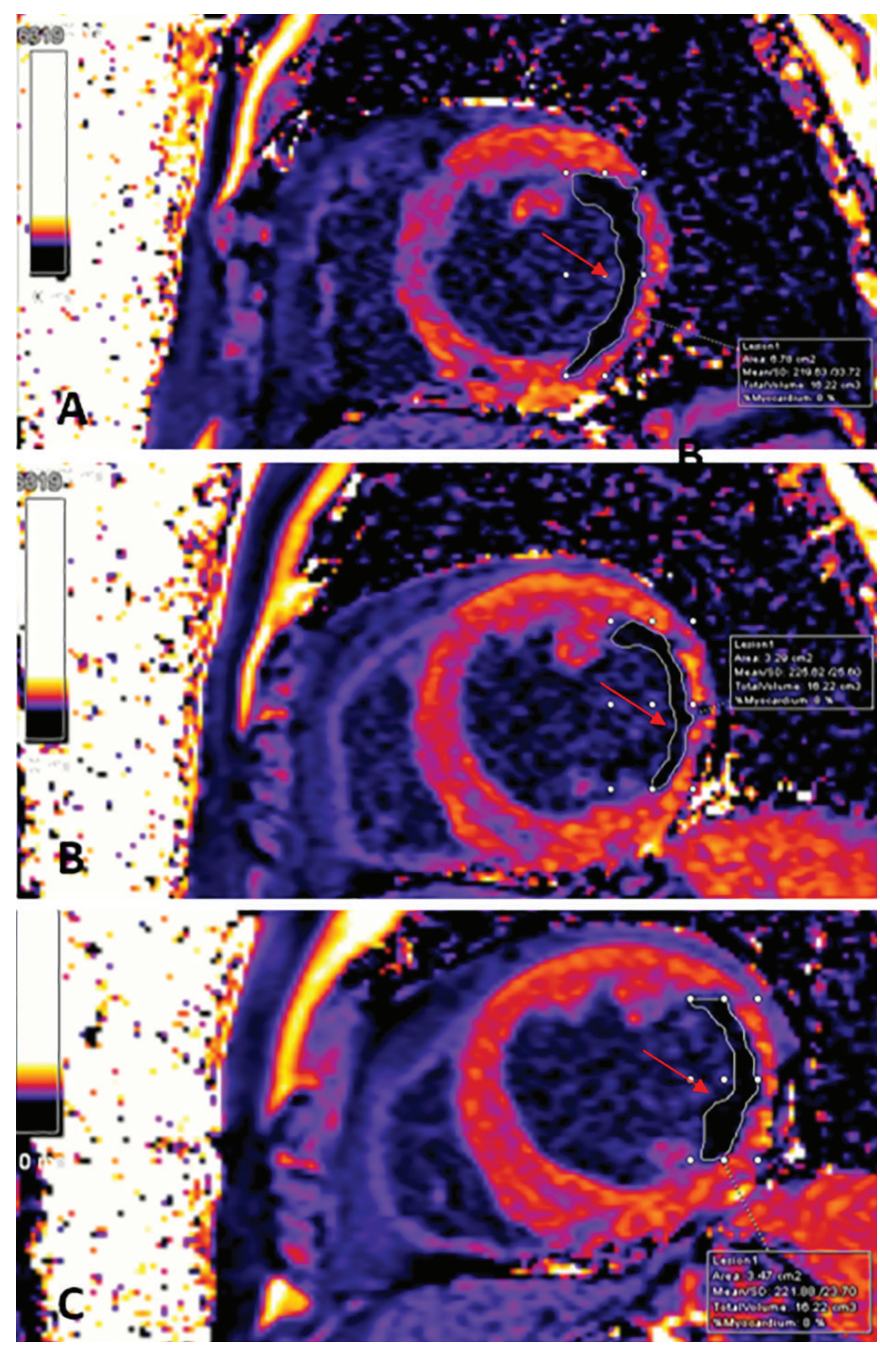

Slika 9. A) Postkontrastna T1 mapa, presek po kratkoj osi: Subendokardna zona sa sniženim vrednostima 11 vremena u bazalnom anterolateralnom i inferolateralnom segmentu; B) Postkontrastna T1 mapa, presek po kratkoj osi: Subendokardna zona sa sniženim vrednostima T1 vremena u medijalnom anterolateralnom i inferolateralnom segmentu; () Postkontrastna T1 mapa, presek po kratkoj osi: Subendokardna zona sa sniženim vrednostima $\mathrm{T} 1$ vremena u apikalnom lateralnom segmentu

Figure 9. A) Post-contrast T1 myocardial mapping, short axis view: Subendocardial zone with decreased mean post-contrast T1 time in the basal anterolateral and inferolateral segments; B) Post-contrast T1 myocardial mapping, short axis view: Subendocardial zone with decreased values of mean post-contrast $T 1$ time in the medial anterolateral and inferolateral segments; C) Post-contrast T1 myocardial mapping, short axis view: Subendocardial zone with decreased values of mean post-contrast $\mathrm{T} 1$ time in the apical lateral segment

stenosis of the right coronary artery. The patient was presented to the Heart Team which decided to estimate the hemodynamic significance of LAD stenosis and then make a decision on further treatment. It was estimated that the stenosis of the left anterior descending artery was not hemodynamically significant, so percutaneous coronary intervention $(\mathrm{PCl})$ of the right coronary artery was performed, and the patient was left on optimal medical therapy and advised to reduce cardiovascular risk factors as much as possible. This case shows that, 


\section{OŠTEĆENJE MIOKARDA I MIOKARDNA INFLAMACIJA KOD PACIJENATA SA/POSLE KOVID-19 INFEKCIJE}

\section{Patofiziološki supstrat}

Tokom akutne faze KOVID-19 infekcije, različiti mehanizmi mogu biti odgovorni za oštećenje miokarda. Hipoksija i mikrotromboza, koje su izraženije kod pacijenata sa teškim oblikom bolesti, mogu uticati na miokard i izazvati oštećenje miokarda [7]. Direktan citopatogeni efekat virusa može dovesti do nekroze kardiomiocita i potencijalne inflamacije miokarda. Manja studija italijanskih istraživača potvrdila je prisustvo genoma virusa i proteina u uzorcima srčanog mišića kod pacijenata sa KOVID-19 infekcijom [8]. Određeni skorovi predikcije mogu biti korisni u stratifikaciji pacijenata sa povišenim rizikom od razvoja teških formi bolesti [9]. Različiti laboratorijski parametri, uključujući i citokine, označeni su kao važni prediktori težine infekcije i mortaliteta i odgovorni su za hiperinflamatorni sindrom i posledično pogoršanje funkcije različitih sistem organa [10]. Citokini takođe mogu izazvati indirektno oštećenje miokarda. Pokazalo se da određena grupa pacijenata može imati povišene vrednosti citokina nedeljama nakon akutne infekcije, što je moguće objašnjenje produženog ili kasnog oštećenja miokarda [11]. Pokazano je da povišeni nivoi citokina i markera nekroze miokarda kod pacijenata sa KOVID-19 infekcijom mogu biti povezani sa sniženom ejekcionom frakcijom, što može biti veoma značajno u daljoj prognozi ovih pacijenata [12]. Autonomna disfunkcija nakon akutne infekcije može dovesti do posturalne ortostatske tahikardije i sinusne tahikardije, što je uobičajeni nalaz dvadesetčetvoročasovnog praćenja Holter EKG-om kod pacijenata nakon KOVID-19 infekcije [13]. Međutim, fokalni miokarditis može biti fokus vrlo ozbiljnih, životno ugrožavajućih aritmija kod osoba sa post-KOVID mioperikarditisnim sindromom. Kardiomagnetna rezonanca je zlatni standard za dijagnozu ovih patoloških promena.

\section{Simptomi i znaci}

Postakutni KOVID-19 sindrom podrazumeva perzistirajuće simptome, kao i odložene ili dugotrajne komplikacije infekcije SARS-KoV-2 virusom, koje se održavaju i nakon 4 nedelje od pojave prvih simptoma [14]. Stariji ljudi i ljudi sa komorbiditetima imaju veći rizik za nastanak post-KOVID sindroma. Među brojnim simptomima koji se javljaju, kao najčešći su se pokazali umor, otežano disanje, bol u grudima i lupanje srca. Ovi simptomi takođe mogu ukazivati i na pogoršanje primarne bolesti pacijenta, najčešće kardiovaskularne ili respiratorne. lako su ovi simptomi obično blagi, oni značaj- in the same patient, two etiologically different pathologies of the cardiac muscle can exist - both coronary disease and a focal inflammation lesion, i.e., myocarditis.

\section{MYOCARDIAL DAMAGE AND MYOCARDIAL INFLAMMATION IN PATIENTS WITH/AFTER COVID-19 INFECTION}

\section{Pathophysiological substrate}

In the setting of acute COVID-19 infection, different mechanisms may be responsible for myocardial damage. Hypoxia and microthrombosis, pronounced in patients with the severe form of the disease, may affect the myocardium and cause myocardial injury [7]. Direct viral involvement with its cytopathic effect leads to the necrosis of cardiomyocytes and potentially to myocardial inflammation. A small study carried out by Italian researchers confirmed the presence of the viral genome and proteins in cardiac samples of COVID-19 patients [8]. Various predictive scores have been developed to stratify patients with increased risk of developing the severe form of the disease [9]. Different laboratory parameters, including cytokines, are marked as important predictors of infection severity and mortality, and are responsible for hyperinflammatory syndrome and subsequently multi-organ failure [10]. Cytokines may also induce indirect myocardial damage. It has been shown that a certain group of patients may have elevated cytokine levels weeks after the acute infection, providing a possible explanation of prolonged or late myocardial damage [11]. It has been demonstrated that elevated levels of cytokines and cardiac markers in patients with COVID-19 may be linked to reduced ejection fraction, which can be highly significant for the further prognosis of these patients [12]. Autonomic dysfunction after acute infection can result in postural orthostatic tachycardia and subsequently sinus tachycardia, which is a common finding of 24hour ECG monitoring in patients, after COVID-19 infection [13]. However, focal myocarditis may be the focus of very serious, life-threatening arrythmias in patients with post-COVID myopericarditis syndrome. Cardiac magnetic resonance imaging is the golden standard for diagnosing these pathologies.

\section{Symptoms and signs}

Post-acute COVID-19 is defined as persistent symptoms and delayed or long-term complications of SARS-CoV-2 infection beyond 4 weeks from the onset of symptoms [14]. Older people and people with comorbidities are the most likely to experience prolonged COVID-19 symptoms. Among many symptoms, it has been shown that fatigue, shortness of breath, chest pain, and 
no utiču na kvalitet života pacijenata, povećavajući potrebu za odgovarajućim dijagnostičkim pristupom i daljim lečenjem, što dovodi do pritiska na zdravstvene ustanove i rasta materijalnih troškova [15]. Velika opservaciona studija u Sjedinjenim Američkim Državama pokazala je da je 32,6\% pacijenata imalo perzistirajuće simptome dva meseca nakon infekcije, od kojih su najčešći dispneja, kašalj i gubitak mirisa ili ukusa [16]. Kahvajo-Šnajder i saradnici utvrdili su da se skoro jedna trećina pacijenata osećala lošije u periodu nakon preležane infekcije u odnosu na akutnu fazu bolesti [17].

\section{Dijagnoza}

Klinička evaluacija pacijenata, kao i primena različitih dijagnostičkih metoda snimanja, uglavnom se primenjuje kod pacijenata sa perzistentnim kardiovaskularnim simptomima nakon KOVID-19 infekcije. Elektrokardiografski zapis i ehokardiografski pregled, kao rutinski dijagnostički modaliteti, savetuju se kod svakog pacijenta koji ima kardiovaskularne simptome, a zavisno od slučaja, indikovane su i senzitivnije metode snimanja, uključujući i magnetnu rezonancu srca. Inflamacija miokarda nakon KOVID-19 infekcije je najčešće fokalna $i$ često se ne može detektovati rutinskim ehokardiografskim pregledom, pri čemu je i ejekciona frakcija najčešće očuvana ili lako snižena, dok nalaz dvadesetčetvoročasovnog praćenja Holter EKG-om uglavnom registruje sinusnu tahikardiju, bez značajnih poremećaja ritma [18]. Maligne ventrikularne aritmije mogu se videti u teškim oblicima inflamacije miokarda, i povezane su sa sniženom ejekcionom frakcijom, što obično zahteva hospitalizaciju radi dalje dijagnostike i lečenja ovih pacijenata [19].

\section{Lečenje i prognoza}

Terapija ordinirana za prethodno dijagnostikovana kardiovaskularna oboljenja ne bi trebalo da se obustavlja tokom akutne faze KOVID-19 infekcije ili nakon toga, jer bi prestanak adekvatne terapije mogao da dovede do pogoršanja postojećeg kardiovaskularnog statusa [20]. Niske doze beta blokatora mogu biti važne u regulaciji srčane frekvencije i smanjenju adrenergičke aktivnosti kod pacijenata sa tahikardijom [21]. Terapija vitaminskim suplementima i oligomineralima može da dovede do jačanja imunskih mehanizama i da time obezbedi odgovarajuću odbranu od direktnog ili indirektnog štetnog delovanja virusa. Ukupan dugoročni uticaj i posledice KOVID-19 infekcije na kardiovaskularni sistem tek treba da se utvrde.

\section{Oporavak}

Oporavak nakon KOVID-19 infekcije je izuzetno važan, posebno kod fizički aktivnih pojedinaca ili profesionalnih palpitations are the most common. These symptoms may also indicate the exacerbation of the patient's primary disease, most likely cardiovascular or respiratory. Although these symptoms are usually mild, they significantly affect the patient's quality of life, increasing the need for proper diagnosis and treatment [15]. A large observational study in the United States of America reported that $32.6 \%$ patients had persistent symptoms two months after the infection, with dyspnea, cough and loss of smell or taste as the most common ones [16]. Carvalho-Schneider et al. reported that almost one-third of patients were feeling worse in the post-COVID period than at the onset of acute COVID-19 infection [17].

\section{Diagnosis}

Clinical and imaging evaluation of patients after COVID-19 should be considered primarily for patients with persistent cardiovascular symptoms. ECG and echocardiogram, as routine modalities, should be performed in every patient reporting cardiovascular symptoms, followed by more advanced cardiovascular imaging modalities, including cardiac magnetic resonance, on a case-to-case basis. Myocardial inflammation after COVID-19 is usually focal and often undetectable by routine echocardiography, with preserved or mildly reduced ejection fraction, while the finding of 24-hour ECG monitoring generally reveals sinus tachycardia, without significant cardiac rhythm abnormalities [18]. Malignant ventricular arrhythmias may be seen in severe forms of myocardial inflammation and are linked with the decrease in ejection fraction, which usually requires hospitalization for further diagnostics and treatment [19].

\section{Treatment and prognosis}

The regular cardiovascular treatment regimen should not be suspended during the acute phase of COVID-19 or after the infection has passed, as discontinuation of the guideline therapy may exacerbate existing cardiovascular conditions [20]. Low-dose beta blockers may be important in heart rate management and in reducing adrenergic activity in patients with tachycardia [21]. Therapy with vitamin and oligomineral supplements can boost immune mechanisms and provide a proper defense against direct or indirect viral involvement. The overall long-term impact of cardiac involvement in COVID-19 is yet to be established.

\section{Recovery}

Recovery after COVID-19 is extremely important, especially in physically active individuals or professional athletes. In individuals with signs of direct or indirect viral cardiac involvement, following the return-to-play 
sportista. Kod osoba sa znacima direktnog ili indirektnog oštećenja srca uzrokovanog virusom, preporučuje se poštovanje protokola postepenog povratka fizičkoj aktivnosti [22]. U slučaju mladih profesionalnih sportista sa prethodnom KOVID-19 infekcijom, važno je da takve osobe imaju najmanje dve nedelje odmora od pojave prvih simptoma, uključujući najmanje sedam dana od povlačenja svih simptoma, ili prestanka uzimanja terapije u okviru KOVID-19 terapijskog protokola. Kod sportista sa teškim oblikom KOVID-19 infekcije i potvrđenom miokardnom povredom ili inflamacijom miokarda, preporučuje se pauza od najmanje $3-6$ meseci do potpunog povlačenja znakova i simptoma upale miokarda, uz dalje praćenje kliničkog statusa [23]. Postepeni povratak u trenažni proces, uz pažljivo praćenje simptoma (bol u grudima, umor, lupanje srca, vrtoglavice ili nesvestice), klinički pregled, kao i dalja dijagnostika, ukoliko je to potrebno, sprečiće moguće komplikacije opasne po život.

\section{MAGNETNA REZONANCA SRCA KAO ZLATNI STANDARD ZA NEINVAZIVNU DIJAGNOSTIKU PACIJENATA SA INFLAMACIJOM MIOKARDA NAKON KOVID-19 INFEKCIJE}

Uloga magnetne rezonance srca kod pacijenata sa kardiovaskularnim simptomima nakon KOVID-19 infekcije je od velikog značaja. Većina ovih pacijenata ima očuvanu globalnu sistolnu funkciju, blage ili umerene simptome, kao i uglavnom normalan nalaz laboratorijskih analiza, pa ne postoji opravdana potreba za miokardnom biopsijom u cilju potvrde eventualnog postojanja inflamacije miokarda. Kada je u pitanju optimalno vreme za kardiomagnetnu rezonancu, najbolje je da se ona sprovede što je ranije moguće nakon pojave simptoma, s obzirom da ehokardiografski pregled uglavnom nije dovoljan za utvrđivanje akutnog miokarditisa ili perikarditisa [24].

Dijagnoza tipičnog miokarditisa se oslanja na Lake-Louise kriterijume i detekciju edema miokarda, nekroze i ožiljka miokarda [25]. Pored LGE fenomena, koji može ukazivati na nekrozu ili fibrozu miokarda, novije sekvence magnetne rezonance srca, pre svega miokardne mape (engl. myocardial mapping), mogu pružiti širu sliku oštećenja miokarda, stepena zahvaćenosti miokarda oštećenjem, kao i njegovog mogućeg uticaja na funkciju leve komore. Dopunjeni Lake-Louise kriterijumi sada obuhvataju i vrednosti miokardnih mapa (vrednosti T2 i nativnog T1 vremena, frakcija ekstracelularnog volumena) kao standardne kriterijume za potvrdu prisustva edema miokarda i fibroze [26]. Prisustvo edema miokarda nakon KOVID-19 infekcije može se otkriti putem miokardnih mapa kod velikog broja pacijenata sa kardiovaskularnim simptomima, čak i bez prisustva $L G E$ fenomena. lako su ovi nalazi češći kod protocols is recommended [22]. In young professional athletes with prior COVID-19 infection, it is important to have at least two weeks rest after symptom onset, including a minimum of seven days after the resolution of all symptoms, or after the cessation of therapy prescribed within the COVID-19 treatment protocol. In athletes with the severe form of COVID-19 and confirmed myocardial involvement, or myocardial inflammation, it is recommended to cease sports activities for at least $3-6$ months until the complete resolution of symptoms and signs of acute myocardial inflammation, with recommended further clinical follow-up [23]. Gradual return to play, with close monitoring of symptoms (chest pain, fatigue, palpitations, dizziness or fainting), physical examination, and further diagnostics, if necessary, will prevent possible life-threatening complications.

CARDIAC MAGNETIC RESONANCE IMAGING AS THE GOLDEN STANDARD FOR NON-INVASIVE DIAGNOSTICS OF PATIENTS WITH MYOCARDI-

\section{AL INFLAMMATION AFTER COVID-19}

The role of cardiac magnetic resonance imaging in patients with cardiovascular symptoms after COVID-19 is of great importance. Most of these patients have a preserved global systolic function, with mild or moderate symptoms, as well as a predominantly normal finding of laboratory results, which is why there is no justifiable reason for performing myocardial biopsy with the aim of potentially confirming the diagnosis of myocarditis. The optimal time to perform CMR would be as early as possible after the onset of symptoms, as echocardiography is usually inconclusive, while the patient may indeed have acute myocardial of pericardial involvement [24].

The diagnosis of typical myocarditis relies on the Lake-Louise criteria and the detection of myocardial edema, necrosis, and myocardial scarring [25]. In addition to the left gadolinium enhancement phenomenon, which can indicate myocardial necrosis or fibrosis, novel cardiac magnetic resonance methods, primarily myocardial mapping, can provide a wider image of myocardial damage, its extent, and its possible effect on left ventricular function. The updated Lake-Louise criteria now includes implemented myocardial mapping values (T2, native $\mathrm{T} 1$ mapping and $E C V$ ) as standard criteria for confirming the presence of myocardial edema and fibrosis [26]. The presence of myocardial edema in patients after COVID-19 is detectable via myocardial mapping in a large portion of patients with cardiovascular symptoms, even without detected late gadolinium enhancement. Although these findings are more common in younger, previously healthy individuals, the presence of myocardial 
mlađih, ranije zdravih osoba, postojanje oštećenja miokarda ovog tipa može uticati na osobe sa pridruženim prethodnim kardiovaskularnim oboljenjima i dovesti do njihovog posledičnog pogoršanja.

Puntman i saradnici su, u svom radu, registrovali znakove oštećenja miokarda na magnetnoj rezonanci srca kod $78,0 \%$ i akutnu inflamaciju miokarda kod $60,0 \%$ pacijenata sa blagim do umerenim simptomima koji su imali povišene vrednosti visoko osetljivog troponina tokom akutne infekcije ili nakon KOVID-19 infekcije [27]. Najčešće su bili zahvaćeni interventrikularni septum, bazalni i medijalni segmenti anteriornog i anterolateralnog zida, kao i inferiornog i inferolateralnog zida, gde su uočeni mezomiokardni i subepikardni edem ili $L G E$ fenomen. Takođe je važno napomenuti da su, kod drugih tipova virusnih miokarditisa, uglavnom zahvaćeni inferiorni i inferolateralni segmenti leve komore. Edem miokarda je takođe uočen i na miokardnim mapama. Značajnim su se smatrale vrednosti globalnog nativnog $\mathrm{T} 1$ vremena koje su iznosile više od $1.136 \mathrm{~ms}$, kao i vrednosti T2 vremena koje su bile iznad $40 \mathrm{~ms}$ [27]. Pacijenti sa registrovanim LGE fenomenom imali su značajno snižen globalni cirkumferentni strain leve komore, kao i globalni cirkumferentni i longitudinalni strain desne komore [28].

Važno je napomenuti da pacijenti sa post-KOVID simptomima, kod kojih je indikovana magnetna rezonanca srca, mogu imati i prethodno neotkrivena kardiološka oboljenja, uključujući strukturne bolesti srca, kardiomiopatije ili ishemiju miokarda. Zbog toga je izuzetno važno ne samo tragati za oštećenjem miokarda, u smislu miokarditisa, već i steći širu sliku pacijentovog kliničkog stanja, te tragati i za drugim kardiološkim oboljenjima, koja mogu biti uzrok simptoma kod ovih pacijenata.

Zahvaćenost perikarda je značajan aspekt kod pacijenata sa kardiovaskularnim simptomima nakon KOVID-19 infekcije. Brito i saradnici su otkrili da je među 160 sportista sa blagim do umerenim simptomima KOVID-19 infekcije, 39,5\% pacijenata imalo samo zahvaćenost perikarda, i to uz lateralni zid leve komore u većini slučajeva, dok je kod $22,0 \%$ bio zahvaćen i miokard i perikard [29]. Globalna sistolna funkcija leve komore je bila očuvana kod svih učesnika, bez statistički značajne razlike u poređenju sa zdravim ispitanicima iz kontrolne grupe. Zahvaćenost perikarda kod ovih pacijenata se uglavnom manifestovala u vidu rezidualnih džepova perikardnog izliva ili kao pojačanje intenziteta signala perikarda na postkontrastnim (LGE) sekvencama (engl. late pericardial echancement). Prema nalazima magnetne rezonance srca, većina ovih pacijenata je klasifikovana pod subakutnu ili rekovalescentnu fazu, jer većina njih nije imala znakove tipične akutne inflamacije perikarda. Ovo je važno naglasiti, jer se akutna faza verovatno javljala ranije u kliničkom damage of this type can affect people with associated previous cardiovascular diseases and exacerbate these diseases.

In their study, Puntmann et al. revealed cardiac involvement on CMR images in $78.0 \%$ and ongoing myocardial inflammation in $60.0 \%$ of patients with mild to moderate symptoms who had had elevated values of high-sensitivity troponin during the acute infection or after COVID-19 [27]. The most commonly affected segments were the interventricular septum, the basal and medial segments of the anterior and anterolateral wall, as well as the inferior and inferolateral wall at the base and mid-chamber, with mesomyocardial and subepicardial edema or the LGE phenomenon. It is also important to note that, in other types of viral myocarditis, the inferior and inferolateral segments of the left ventricle are usually affected. Myocardial edema was also detected by myocardial mapping sequences. The values of global native $\mathrm{T} 1$ above $1,136 \mathrm{~ms}$ and $\mathrm{T} 2$ values above $40 \mathrm{~ms}$ were considered significant [27]. Patients with detected late gadolinium enhancement (LGE) phenomenon had significantly decreased LV peak global circumferential strain (GCS), RV peak GCS, and RV peak global longitudinal strain (GLS) [28].

It is significant to note that patients with postCOVID symptoms indicated for cardiac magnetic resonance imaging can have previously undiscovered cardiac conditions, including structural cardiac diseases, cardiomyopathy or ischemia. This is why it is extremely important not only to search for myocardial damage, in terms of myocarditis, but also to get a wider image of the patient's current clinical condition and look for other cardiological diseases, which may be the cause of symptoms in these patients.

Pericardial involvement is a significant aspect in patients with cardiovascular symptoms after COVID-19. Brito et al. found, among 160 athletes who had had mild to moderate COVID-19 symptoms, that $39.5 \%$ of the participants had only pericardial involvement, with the lateral pericardium affected in a majority of the cases, while $22.0 \%$ of patients had both myocardial and pericardial involvement [29]. The global ejection fraction was preserved in all participants, without a statistically significant difference, as compared to healthy controls. Pericardial involvement in these patients was detected mainly as residual pockets of pericardial effusion or late pericardial enhancement, revealing an increased vascularity with pericardial inflammation. According to the CMR findings, a majority of these patients was classified under the subacute or convalescing phase, as most of them had no signs of typical acute pericardial inflammation. This is important to emphasise, as 
toku KOVID-19 infekcije, posebno kod pacijenata sa kardiovaskularnim simptomima i povišenim markerima inflamacije i nekroze miokarda.

Procena rizika je od izuzetnog značaja, s obzirom da se većina pacijenata obično javlja lekaru u fazi rekonvalescencije sa već razvijenom fibrozom i LGE fenomenom na kardiomagnetnoj rezonanci. Kvantifikacija LGE fenomena je značajna za procenu rizika od potencijalnih životno ugrožavajućih aritmija i naprasne srčane smrti, imajući u vidu činjenicu da je $L G E$ fenomen više povezan sa rizikom od naprasne srčane smrti nego ejekciona frakcija leve komore [30].

\section{ZAKLJUČAK}

Inflamacija miokarda nakon KOVID-19 infekcije je realan klinički scenario koji značajno može uticati na kvalitet života, dalje lečenje i prognozu. Magnetna rezonanca srca, kao sofisticirana dijagnostička ne-jonizujuća metoda snimanja, može pružiti ključne informacije o postojanju inflamacije miokarda, stepenu proširenosti inflamacije i funkciji leve komore kod pacijenata sa kardiovaskularnim simptomima nakon KOVID-19 infekcije, te stoga predstavlja zlatni standard za dijagnostiku post-KOVID mioperikarditisnog sindroma. Buduće studije na većem broju pacijenata će definitivno pružiti više informacija o dugoročnim efektima ovog važnog kliničkog entiteta.

\section{ZAHVALNICA}

Autori žele da odaju priznanje svim zdravstvenim radnicima koji su u prvoj liniji borbe protiv bolesti KOVID-19 u Republici Srbiji i svetu.

\section{SPISAK SKRAĆENICA}

NMR - nuklearna magnetna rezonanca

KOVID-19 - bolest izazvana koronavirusom 2019 (engl. coronavirus disease of 2019)

EKG - elektrokardiogram

$\mathrm{ECV}$ - engl. extracellular volume

EDVI - engl. end-diastolic volume index

$\mathrm{EF}$ - ejekciona frakcija

LGE - engl. late gadolinium enhancement

SARS-KoV-2 - ozbiljni akutni respiratorni sindrom korona virus 2 (engl. severe acute respiratory syndrome coronavirus 2 - SARS-CoV-2)

NSS - naprasna srčana smrt

STIR - engl. short tau inversion recovery

Sukob interesa: Nije prijavljen. the acute phase probably occurs earlier in the clinical course of COVID-19, especially in patients with cardiovascular symptoms and positive cardiac and inflammatory markers.

Risk assessment is important, as most of the patients usually present in the convalescent phase, after fibrosis and the LGE phenomenon had already developed and are visible on CMR. The quantification of the LGE phenomenon is significant for estimating the risk of potential life-threatening arrhythmias and sudden cardiac death, as the LGE phenomenon has been associated with the risk of SCD more than reduced ejection fraction [30].

\section{CONCLUSION}

Myocardial inflammation after COVID-19 is a real clinical scenario that can significantly affect the quality of life, further treatment, and prognosis. Cardiac magnetic resonance imaging, as a sophisticated, non-radiating imaging modality, can provide crucial information on the presence of myocardial inflammation, its extent, and its possible effect on left ventricular function in patients with cardiovascular symptoms after COVID-19 infection, which is why it is the golden standard for diagnosing post-COVID myopericarditis syndrome. Further larger studies will definitely shed more light on the long-term effects of this important condition.

\section{ACKNOWLEDGMENTS}

The authors would like to acknowledge all healthcare professionals who are the first line of defense against COVID-19, in the Republic of Serbia and worldwide.

\section{LIST OF ABBREVIATIONS AND ACRONYMS}

CMR - cardiac magnetic resonance imaging

COVID-19 - coronavirus disease of 2019

ECG - electrocardiogram

ECV - extracellular volume

EDVI - end-diastolic volume index

EF - ejection fraction

LGE - late gadolinium enhancement

SARS-CoV-2 - severe acute respiratory syndrome coronavirus 2

$S C D$ - sudden cardiac death

STIR - short tau inversion recovery

Conflict of interest: None declared. 


\section{LITERATURA / REFERENCES}

1. Lai CC, Ko WC, Lee PI, Jean SS, Hsueh PR. Extra-respiratory manifestations of COVID-19. Int J Antimicrob Agents. 2020 Aug;56(2):106024. doi: 10.1016/j. ijantimicag.2020.106024.

2. Bandyopadhyay D, Akhtar T, Hajra A, Gupta M, Das A, Chakraborty S, et al. COVID-19 Pandemic: Cardiovascular Complications and Future Implications. Am J Cardiovasc Drugs. 2020 Aug;20(4):311-24. doi: 10.1007/s40256-020-00420-2.

3. Armstrong RA, Kane AD, Cook TM. Outcomes from intensive care in patients with COVID-19: a systematic review and meta-analysis of observational studies. Anaesthesia. 2020 0ct;75(10):1340-9. doi: 10.1111/anae.15201.

4. Liaqat A, Ali-Khan RS, Asad M, Rafique Z. Evaluation of myocardial injury patterns and ST changes among critical and non-critical patients with coronavirus-19 disease. Sci Rep. 2021 Mar 1;11(1):4828. doi: 10.1038/s41598-02184467-4.

5. Guzik TJ, Mohiddin SA, Dimarco A, Patel V, Savvatis K, Marelli-Berg FM, et al. COVID-19 and the cardiovascular system: implications for risk assessment, diagnosis, and treatment options. Cardiovasc Res. 2020 Aug 1;116(10):166687. doi: $10.1093 / \mathrm{cvr} / \mathrm{cvaa} 106$.

6. Seetharam $\mathrm{K}$, Lerakis $\mathrm{S}$. Cardiac magnetic resonance imaging: the future is bright. F1000Res. 2019 Sep 13;8:F1000 Faculty Rev-1636. doi: 10.12688/ f1000research.19721.1.

7. Babapoor-Farrokhran S, Gill D, Walker J, Rasekhi RT, Bozorgnia B, Amanullah A. Myocardial injury and COVID-19: Possible mechanisms. Life Sci. 2020 Jul 15;253:117723. doi: 10.1016/j.lfs.2020.117723.

8. Bulfamante GP, Perrucci GL, Falleni M, Sommariva E, Tosi D, Martinelli C, et al. Evidence of SARS-CoV-2 Transcriptional Activity in Cardiomyocytes of COVID-19 Patients without Clinical Signs of Cardiac Involvement. Biomedicines. 2020 Dec 18;8(12):626. doi: 10.3390/biomedicines 8120626.

9. Zdravkovic M, Popadic V, Klasnja S, Pavlovic V, Aleksic A, Milenkovic M, et al. Development and Validation of a Multivariable Predictive Model for Mortality of COVID-19 Patients Demanding High 0xygen Flow at Admission to ICU: AIDA Score. Oxid Med Cell Longev. 2021 Jun 30;2021:6654388. doi: 10.1155/2021/6654388.

10. Popadic V, Klasnja S, Milic N, Rajovic N, Aleksic A, Milenkovic M, et al. Predictors of Mortality in Critically III COVID-19 Patients Demanding High Oxygen Flow: A Thin Line between Inflammation, Cytokine Storm, and Coagulopathy. Oxid Med Cell Longev. 2021 Apr 20;2021:6648199. doi: 10.1155/2021/6648199.

11. Hu B, Huang S, Yin L. The cytokine storm and COVID-19. J Med Virol. 2021 Jan;93(1):250-6. doi: 10.1002/jmv.26232.

12. Yi Y, Xu Y, Jiang H, Wang J. Cardiovascular Disease and COVID-19: Insight From Cases With Heart Failure. Front Cardiovasc Med. 2021 Mar 15;8:629958. doi: 10.3389/fcvm.2021.629958.

13. Dani M, Dirksen A, Taraborrelli P, Torocastro M, Panagopoulos D, Sutton R, et al. Autonomic dysfunction in 'long COVID': rationale, physiology and management strategies. Clin Med (Lond). 2021 Jan;21(1):e63-e67. doi: 10.7861/ clinmed.2020-0896.

14. Nalbandian A, Sehgal K, Gupta A, Madhavan MV, McGroder C, Stevens JS, et al. Post-acute COVID-19 syndrome. Nat Med. 2021 Apr;27(4):601-15. doi: 10.1038/s41591-021-01283-z.

15. Carfì A, Bernabei R, Landi F; Gemelli Against COVID-19 Post-Acute Care Study Group. Persistent Symptoms in Patients After Acute COVID-19. JAMA. 2020 Aug 11;324(6):603-5. doi: 10.1001/jama.2020.12603.

16. Chopra V, Flanders SA, O'Malley M, Malani AN, Prescott HC. Sixty-Day Outcomes Among Patients Hospitalized With COVID-19. Ann Intern Med. 2021 Apr;174(4):576-8. doi: 10.7326/M20-5661.
17. Carvalho-Schneider C, Laurent $E$, Lemaignen $A$, Beaufils $E$, Bourbao-Tournois C, Laribi S, et al. Follow-up of adults with noncritical COVID-19 two months after symptom onset. Clin Microbiol Infect. 2021 Feb;27(2):258-63. doi: 10.1016/j.cmi.2020.09.052.

18. Weckbach LT, Curta A, Bieber S, Kraechan A, Brado J, Hellmuth JC, et al. Myocardial Inflammation and Dysfunction in COVID-19-Associated Myocardial Injury. Trends Cardiovasc Med. 2020 Nov;30(8):451-60. doi: 10.1016/j. tcm.2020.08.002.

19. Manolis AS, Manolis AA, Manolis TA, Apostolopoulos EJ, Papatheou D, Melita H. COVID-19 infection and cardiac arrhythmias. Trends Cardiovasc Med. 2020 Nov;30(8):451-60. doi: 10.1016/j.tcm.2020.08.002.

20. Zhang P, Zhu L, Cai J, Lei F, Qin JJ, Xie J, et al. Association of Inpatient Use of Angiotensin-Converting Enzyme Inhibitors and Angiotensin II Receptor Blockers With Mortality Among Patients With Hypertension Hospitalized With COVID-19. Circ Res. 2020 Jun 5;126(12):1671-81. doi: 10.1161/CIRCRESAHA.120.317134.

21. Vasanthakumar N. Beta-Adrenergic Blockers as a Potential Treatment for COVID-19 Patients. Bioessays. 2020 Nov;42(11):e2000094. doi: 10.1002/ bies.202000094.

22. Wilson MG, Hull JH, Rogers J, Pollock N, Dodd M, Haines J, et al. Cardiorespiratory considerations for return-to-play in elite athletes after COVID-19 infection: a practical guide for sport and exercise medicine physicians. $\mathrm{Br} J$ Sports Med. 2020 0ct;54(19):1157-61. doi: 10.1136/bjsports-2020-102710.

23. McKinney J, Connelly KA, Dorian P, Fournier A, Goodman JM, Grubic N, et al. COVID-19-Myocarditis and Return to Play: Reflections and Recommendations From a Canadian Working Group. Can J Cardiol. 2021 Aug;37(8):1165-74. doi: 10.1016/j.cjca.2020.11.007.

24. Ojha V, Verma M, Pandey NN, Mani A, Malhi AS, KumarS, et al. Cardiac Magnetic Resonance Imaging in Coronavirus Disease 2019 (COVID-19): A Systematic Review of Cardiac Magnetic Resonance Imaging Findings in 199 Patients. J Thorac Imaging. 2021 Mar 1;36(2):73-83. doi: 10.1097/RTI.0000000000000574.

25. Friedrich MG, Sechtem U, Schulz-Menger J, Holmvang G, Alakija P, Cooper LT, et al.; International Consensus Group on Cardiovascular Magnetic Resonance in Myocarditis. Cardiovascular magnetic resonance in myocarditis: A JACC White Paper. J Am Coll Cardiol. 2009 Apr 28;53(17):1475-87. doi: 10.1016/j. jacc.2009.02.007.

26. Ferreira VM, Schulz-Menger J, Holmvang G, Kramer CM, Carbone I, Sechtem $U$, et al. Cardiovascular Magnetic Resonance in Nonischemic Myocardial Inflammation: Expert Recommendations. J Am Coll Cardiol. 2018 Dec 18;72(24):3158-76. doi: 10.1016/j.jacc.2018.09.072.

27. Puntmann V0, Carerj ML, Wieters I, Fahim M, Arendt C, Hoffmann J, et al. Outcomes of Cardiovascular Magnetic Resonance Imaging in Patients Recently Recovered From Coronavirus Disease 2019 (COVID-19). JAMA Cardiol. 2020 Nov 1;5(11):1265-73. doi: 10.1001/jamacardio.2020.3557.

28. Wang H, Li R, Zhou Z, Jiang H, Yan Z, Tao X, et al. Cardiac involvement in COVID-19 patients: mid-term follow up by cardiovascular magnetic resonance. J Cardiovasc Magn Reson. 2021 Feb 25;23(1):14. doi: 10.1186/s12968021-00710-x.

29. Brito D, Meester S, Yanamala N, Patel HB, Balcik BJ, Casaclang-Verzosa G, et al. High Prevalence of Pericardial Involvement in College Student Athletes Recovering From COVID-19. JACC Cardiovasc Imaging. 2021 Mar;14(3):541-55. doi: 10.1016/j.jcmg.2020.10.023.

30. Gräni C, Eichhorn C, Bière L, Murthy VL, Agarwal V, Kaneko K, et al. Prognostic Value of Cardiac Magnetic Resonance Tissue Characterization in Risk Stratifying Patients With Suspected Myocarditis. J Am Coll Cardiol. 2017 Oct 17;70(16):1964-76. doi: 10.1016/j.jacc.2017.08.050. 